\title{
Neolignan Glucosides from Phlomis chimerae Boiss
}

Tayfun Ersöz ${ }^{\mathrm{a}, *}$, İclal Saracoğlu ${ }^{\mathrm{a}}$, Deniz Taşdemira ${ }^{\mathrm{a}}$, Hasan Kırmızıbekmez ${ }^{\mathrm{a}}$, Ali A. Dönmez ${ }^{\mathrm{b}}$, Chris M. Ireland ${ }^{\mathrm{c}}$ and İhsan Çalış ${ }^{\mathrm{a}}$

a Department of Pharmacognosy, Faculty of Pharmacy, Hacettepe University TR 06100,

Ankara, Turkey. Fax: +90-312-3114777. E-mail: tersoz@hacettepe.edu.tr

b Department of Biology, Faculty of Science, Hacettepe University TR 06532,

Ankara, Turkey

c Department of Medicinal Chemistry, College of Pharmacy, University of Utah, Salt Lake City Utah 84112, U. S. A.

* Author for correspondence and reprint requests

Z. Naturforsch. 57c, 221-225 (2002); received December 4, 2001/January 1, 2002

Phlomis, Neolignan Glucosides, (-)-4- $O$-methyldihydrodehydrodiconiferyl alcohol-9'-O- $\beta$-D-glucopyranoside

From the aerial parts of the plant Phlomis chimerae, a new neolignan glucoside, (-)-4 $O$-methyldihydrodehydrodiconiferyl alcohol-9'- $O$ - $\beta$-D-glucopyranoside (1) was characterized along with the known neolignan glucosides, (-)-4-O-methyldehydrodiconiferyl alcohol- $9^{\prime}-O$ $\beta$-D-glucopyranoside (= longifloroside A) (2) and (-)-dihydrodehydrodiconiferyl alcohol-9$O$ - $\beta$-D-glucopyranoside (3). The structure of the new compound was established on the basis of spectroscopic evidence.

\section{Introduction}

Lignans and neolignans belong to an important group of natural products, consisting of two phenylpropane monomers linked through carbon-carbon or carbon-oxygen bonds (Whiting, 1985). So far, only two Phlomis species, P. lycia (Saracoğlu et al., 2002) and P. fruticosa (Ersöz et al., 2001a) have been reported to contain neolignan and lignan glucosides. As a part of a project directed at the chemical characterization of Phlomis species growing in Turkey, we have isolated an iridoid glucoside, lamiide, and four phenylethanoid glycosides, verbascoside (= acteoside), forsythoside B, alyssonoside and leucosceptoside $\mathrm{B}$, together with a phenolic glucoside, syringin, from Phlomis chimerae Boiss. (Ersöz et al., 2001b). Further investigation on the overground parts of this plant yielded a new neolignan glucoside, (-)-4- $O$-methyldihydrodehydrodiconiferyl alcohol-9'- $O$ - $\beta$-D-glucopyranoside (1), along with the known neolignan glucosides, (-)-4- $O$-methyldehydrodiconiferyl alcohol-9'-O- $\beta$-D-glucopyranoside (= longifloroside A) (2) and (-)-dihydrodehydrodiconiferyl alcohol-9-O- $\beta$-D-glucopyranoside (3). The current study describes the structural elucidation of the new glucoside (1).

\section{Experimental}

\section{General experimental procedures}

NMR measurements in $\mathrm{CD}_{3} \mathrm{OD}$ were performed on a Varian spectrometer $(500 \mathrm{MHz}$ for ${ }^{1} \mathrm{H}$ and $125 \mathrm{MHz}$ for ${ }^{13} \mathrm{C}$ ) with a Nalorac MDBG $3 \mathrm{~mm}$ probe. ESIMS were recorded in the positive and negative ion modes on a Finnigan TSQ 7000 spectrometer. For open-column chromatography (CC), polyamide (Polyamid-MN-Polyamid SC-6, Machery-Nagel, Düren), and Kieselgel 60 (0.063$0.200 \mathrm{~mm}$, Merck) were used. Medium-pressure liquid chromatography (MPLC) was performed on a Labomatic glass column $(26 \times 460 \mathrm{~mm}$, i.d.), packed with LiChroprep RP-18, using a Lewa M5 peristaltic pump. For TLC, pre-coated Kieselgel 60 $\mathrm{F}_{254}$ aluminum sheets (Merck) were used. Compounds were detected by UV and $1 \%$ vanillin/ $\mathrm{H}_{2} \mathrm{SO}_{4}$.

\section{Plant material}

Phlomis chimerae Boiss. (Lamiaceae) was collected from Antalya, Çıralı, Turkey, in July 2000. Voucher specimens have been deposited in the Herbarium of the Pharmacognosy Department, Faculty of Pharmacy, Hacettepe University, Ankara, Turkey (HUEF 00-031). 


\section{Extraction and isolation}

The air-dried and powdered aerial parts of $P$. chimerae $(480 \mathrm{~g})$ were extracted twice with $\mathrm{MeOH}$ $(2 \times 2500 \mathrm{ml})$ at $40^{\circ} \mathrm{C}$. After evaporation of the combined extracts in vacuo, $63 \mathrm{~g} \mathrm{MeOH}$ extract was obtained. An aliquot ( $38 \mathrm{~g}$ ) of the crude extract was dissolved in water and the water-insoluble material was removed by filtration. The filtrate was then extracted succesively with $\mathrm{CH}_{2} \mathrm{Cl}_{2}$ $(4 \times 100 \mathrm{ml})$ and $n$-BuOH $(4 \times 100 \mathrm{ml})$, respectively. The $n$-BuOH extract $(14 \mathrm{~g})$ was fractionated over a polyamide column $(150 \mathrm{~g})$, eluting with $\mathrm{H}_{2} \mathrm{O}$ $(500 \mathrm{ml})$ and gradient $\mathrm{MeOH}-\mathrm{H}_{2} \mathrm{O}$ mixtures (25$100 \%$ ) to afford 12 main fractions (A-L). Fr. B $(1.37 \mathrm{~g})$ was subjected to RP-18 MPLC using $\mathrm{H}_{2} \mathrm{O}$ $(200 \mathrm{ml})$ and $\mathrm{MeOH}-\mathrm{H}_{2} \mathrm{O}$ gradients $(10-100 \%$ $\mathrm{MeOH})$ to yield 21 fractions $\left(\mathrm{B}_{1}-\mathrm{B}_{21}\right)$. Fraction $\mathrm{B}_{18}(74 \mathrm{mg})$ was applied to a silica gel column. Elution with $\mathrm{CH}_{2} \mathrm{Cl}_{2}-\mathrm{MeOH}-\mathrm{H}_{2} \mathrm{O}$ mixtures (90:10:1 and 80:20:1 v/v) yielded $3(10 \mathrm{mg})$. Fraction $\mathrm{B}_{20}(39 \mathrm{mg})$ was also chromatographed on a silica gel column eluting with $\mathrm{CH}_{2} \mathrm{Cl}_{2}-\mathrm{MeOH}-\mathrm{H}_{2} \mathrm{O}$ mixtures (90:10:1 and 80:20:1 v/v) to afford a mixture of 1 and 2 ( $4 \mathrm{mg}$ ). Despite all efforts, this mixture could not be separated by normal or reversed phase TLC/CC.

(-)-4-O-methyldihydrodehydrodiconiferyl alcohol-9'-O- $\beta$-D-glucopyranoside (1): ${ }^{1} \mathrm{H} \quad \mathrm{NMR}$ $\left(\mathrm{CD}_{3} \mathrm{OD}, 500 \mathrm{MHz}\right)$ : Table I; ${ }^{13} \mathrm{C}$ NMR $\left(\mathrm{CD}_{3} \mathrm{OD}\right.$, $125 \mathrm{MHz}$ ): Table I; positive-ion ESIMS $\mathrm{m} / z 559$ $[\mathrm{M}+\mathrm{Na}]^{+}$; negative-ion ESIMS $m / z 535[\mathrm{M}-\mathrm{H}]^{-}$.

(-)-4-O-methyldehydrodiconiferyl alcohol-9'$O$ - $\beta$-D-glucopyranoside (2): ${ }^{1} \mathrm{H}$ NMR $\left(\mathrm{CD}_{3} \mathrm{OD}\right.$, $500 \mathrm{MHz})$ : aglycon: $\delta 6.92(1 \mathrm{H}, d, J=2.0 \mathrm{~Hz}, \mathrm{H}-$ 2), $6.93(1 \mathrm{H}, d, J=8.0 \mathrm{~Hz}, \mathrm{H}-5), 5.49(1 \mathrm{H}, d, J=$ $6.5 \mathrm{~Hz}, \mathrm{H}-7), 3.44$ (1H, overlapped, H-8), 6.88 (3H, br $s$, overlapped, H-6, H-2' and H-6' $), 3.80(1 \mathrm{H}$, $\mathrm{H}-9_{\mathrm{b}}$, partly merged with the $3^{\prime}$-OMe signal), 3.73 $(1 \mathrm{H}, d, J=8.0 \mathrm{~Hz}, \mathrm{H}-9 \mathrm{a}), 6.65(1 \mathrm{H}, d, J=11.0 \mathrm{~Hz}$,

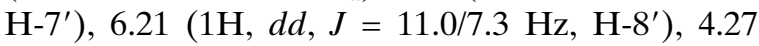
$\left(1 \mathrm{H}, t, J=7.3 \mathrm{~Hz}, \mathrm{H}-9^{\prime}{ }_{\mathrm{a}}\right), 4.48(1 \mathrm{H}, t, J=7.3 \mathrm{~Hz}$, $\mathrm{H}-9^{\prime}{ }_{\mathrm{b}}$ ), 3.84 (3H, $\left.s, 3^{\prime}-\mathrm{OMe}\right), 3.75$ (3H, s, 3-OMe), $3.72(3 \mathrm{H}, s, 4-\mathrm{OMe})$; glucose moiety: $4.32(1 \mathrm{H}, d$, $\left.J=7.3 \mathrm{~Hz}, \mathrm{H}-1^{\prime \prime}\right), 3.22(1 \mathrm{H}, d d, J=7.3 / 8.5 \mathrm{~Hz}, \mathrm{H}-$ $\left.2^{\prime \prime}\right), 3.32\left(1 \mathrm{H}, t, J=8.5 \mathrm{~Hz}, \mathrm{H}-3^{\prime \prime}\right), 3.25(1 \mathrm{H}, t, J=$ $\left.9.4 \mathrm{~Hz}, \mathrm{H}-4^{\prime \prime}\right), 3.31$ (1H, $\left.m, \mathrm{H}-5^{\prime \prime}\right), 3.82\left(1 \mathrm{H}, \mathrm{H}-6^{\prime \prime}{ }_{\mathrm{b}}\right.$, partly merged with the $3^{\prime}$-OMe signal), $3.63(1 \mathrm{H}$, $\left.d d, J=11.9 / 6.0 \mathrm{~Hz}, \mathrm{H}-6^{\prime \prime}{ }_{\mathrm{a}}\right) ;{ }^{13} \mathrm{C} \mathrm{NMR}\left(\mathrm{CD}_{3} \mathrm{OD}\right.$, $125 \mathrm{MHz}$ ): aglycon: $\delta 136.94(s, \mathrm{C}-1), 110.75(d$,
$\mathrm{C}-2), 150.40(s, \mathrm{C}-3), 150.65(s, \mathrm{C}-4), 116.70(d, \mathrm{C}-5)$, 119.48 (d, C-6), 89.09 (d, C-7), 55.55 (d, C-8), 65.94 $(t, \mathrm{C}-9), 56.51\left(q, \mathrm{OCH}_{3}\right), 56.45\left(q, \mathrm{OCH}_{3}\right), 132.46$ $\left(s, \mathrm{C}-1^{\prime}\right), 112.94\left(d, \mathrm{C}-2^{\prime}\right), 145.56\left(s, \mathrm{C}-3^{\prime}\right), 150.40$ $\left(s, \mathrm{C}-4^{\prime}\right), 130.22\left(s, \mathrm{C}-5^{\prime}\right), 119.48\left(d, \mathrm{C}-6^{\prime}\right), 134.22$

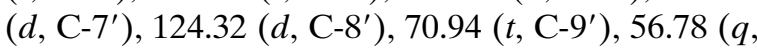
$\left.\mathrm{OCH}_{3}\right)$; glucose moiety: $103.18\left(d, \mathrm{C}-1^{\prime \prime}\right), 75.20(d$, C-2"), $78.17\left(d, \mathrm{C}-3^{\prime \prime}\right), 71.70\left(d, \mathrm{C}-4^{\prime \prime}\right), 78.01$ ( $d, \mathrm{C}-$ $\left.5^{\prime \prime}\right), 62.85\left(t, \mathrm{C}-6^{\prime \prime}\right)$; positive-ion ESIMS $m / z 557$ $[\mathrm{M}+\mathrm{Na}]^{+}$; negative-ion ESIMS $m / z 533[\mathrm{M}-\mathrm{H}]^{-}$.

(-)-Dihydrodehydrodiconiferyl alcohol-9-O- $\beta$ D-glucopyranoside (3): $[\alpha]^{\mathrm{D}_{20}}-18^{\circ}(c 0.1, \mathrm{MeOH})$. The ${ }^{1} \mathrm{H}\left(\mathrm{CD}_{3} \mathrm{OD}, 500 \mathrm{MHz}\right),{ }^{13} \mathrm{C} \mathrm{NMR}\left(\mathrm{CD}_{3} \mathrm{OD}\right.$, $125 \mathrm{MHz}$ ) data were identical with those reported in the literature (Abe and Yamauchi, 1986; Wang and Jia, 1997a; Saracoğlu et al., 2002).

\section{Results and Discussion}

The methanolic extract of the aerial parts of $P$. chimerae was suspended in water and partitioned succesively between $\mathrm{CH}_{2} \mathrm{Cl}_{2}$ and $n$-BuOH. Chromatographic separations of the $n-\mathrm{BuOH}$ extract yielded a mixture of compounds $\mathbf{1}$ and $\mathbf{2}$ as well as pure 3 (Fig. 1).

Compounds $\mathbf{1}$ and $\mathbf{2}$ were obtained as an inseparable $(1: 1)$ mixture, $[\alpha]_{\mathrm{D}}^{20}-26^{\circ}(c 0.1, \mathrm{MeOH})$. The positive ESIMS of this mixture exhibited the pseudomolecular ions $[\mathrm{M}+\mathrm{Na}]^{+}$at $\mathrm{m} / z, 559$ and $\mathrm{m} / z$ 557, while the negative ESIMS showed the ions $[\mathrm{M}-\mathrm{H}]^{-}$at $m / z 535$ and $m / z 533$ for $\mathbf{1}$ and 2 . These data were compatible with the molecular formulae $\mathrm{C}_{27} \mathrm{H}_{36} \mathrm{O}_{11}$ (1) and $\mathrm{C}_{27} \mathrm{H}_{34} \mathrm{O}_{11}$ (2). Although most NMR signals appeared double, indicating a close structural similarity between $\mathbf{1}$ and $\mathbf{2},{ }^{1} \mathrm{H}-{ }^{1} \mathrm{H}$ gCOSY, ${ }^{1} \mathrm{H}_{-}{ }^{13} \mathrm{C}$ gHSQC and ${ }^{1} \mathrm{H}_{-}{ }^{13} \mathrm{C}$ gHMBC experiments allowed to pick the signals for $\mathbf{1}$ and 2 individually.

In the ${ }^{1} \mathrm{H}$ NMR spectrum, five aromatic proton signals were recognized for $\mathbf{1}$ (Table I). Of these, the proton resonances at $\delta 6.92(d, J=2.0 \mathrm{~Hz}, \mathrm{H}$ 2), $6.93(d, J=8.0 \mathrm{~Hz}, \mathrm{H}-5)$ and 6.88 (br s, H6 , overlapped) were observed as an ABX system, suggesting $\mathbf{1}$ to contain a trisubstituted aromatic moiety. The $2 \mathrm{H}$ resonance at $\delta 6.70(\mathrm{br} s)$ was indicative of the presence of an additional tetrasubstituted aromatic moiety in the structure of $\mathbf{1}$. Moreover, the ${ }^{1} \mathrm{H}$ NMR spectrum of $\mathbf{1}$ displayed three methoxy singlets at $\delta 3.81,3.77$ and 3.74 and an anomeric proton signal at $\delta 4.20(d, J=7.3 \mathrm{~Hz})$ 
<smiles>COOC/C=C/c1cc(OC)c2c(c1)C(CO)C(c1ccc(OC)c(OC)c1)O2</smiles><smiles>COCC1c2cc(CCCO)cc(OC)c2OC1c1ccc(O)c(OC)c1</smiles>

Fig. 1. Neolignan glucosides from P. chimerae.

Table I. ${ }^{13} \mathrm{C}$ NMR $\left(\mathrm{CD}_{3} \mathrm{OD}, 125 \mathrm{MHz}\right)$ and ${ }^{1} \mathrm{H}$ NMR $\left(\mathrm{CD}_{3} \mathrm{OD}, 500 \mathrm{MHz}\right)$ data and HMBC correlations for 1.*

\begin{tabular}{|c|c|c|c|c|}
\hline \multicolumn{2}{|l|}{$\mathrm{C} / \mathrm{H}$ Atom } & \multirow{2}{*}{$\frac{\delta_{\mathrm{C}}}{136.0}$} & \multirow[t]{2}{*}{$\delta_{\mathrm{H}} J(\mathrm{~Hz})$} & \multirow[t]{2}{*}{ HMBC } \\
\hline 1 & $\mathrm{C}$ & & & \\
\hline 2 & $\mathrm{CH}$ & 110.8 & $6.92 d(2.0)$ & C-3, C-6 \\
\hline 3 & $\mathrm{C}$ & 150.7 & & \\
\hline 4 & $\mathrm{C}$ & 150.3 & & \\
\hline 5 & $\mathrm{CH}$ & 116.7 & $6.93 d(8.0)$ & $\mathrm{C}-4, \mathrm{C}-6$ \\
\hline 6 & $\mathrm{CH}$ & 119.5 & $6.88 d d(8.0 / 2.0)$ & $\mathrm{C}-1, \mathrm{C}-5$ \\
\hline 7 & $\mathrm{CH}$ & 88.7 & $5.52 d(6.5)$ & $\mathrm{C}-1, \mathrm{C}-2, \mathrm{C}-6$ \\
\hline 8 & $\mathrm{CH}$ & 55.3 & $3.42^{\mathrm{a}}(\mathrm{0.07}$ & C-9 \\
\hline 9 & $\mathrm{CH}_{2}$ & 65.1 & $\begin{array}{l}3.80^{\mathrm{b}} \\
3.72 d(8.0)\end{array}$ & C-7 \\
\hline 3-OMe & $\mathrm{CH}_{3}$ & 56.5 & $3.77 \mathrm{~s}$ & $\mathrm{C}-3$ \\
\hline $4-\mathrm{OMe}$ & $\mathrm{CH}_{3}$ & 56.5 & $3.74 \mathrm{~s}$ & C-4 \\
\hline $1^{\prime}$ & $\mathrm{C}$ & 136.3 & & \\
\hline $2^{\prime}$ & $\mathrm{CH}$ & 114.3 & $6.70 \mathrm{brs}$ & C- $4^{\prime}$ \\
\hline $3^{\prime}$ & $\mathrm{C}$ & 145.2 & & \\
\hline $4^{\prime}$ & $\mathrm{C}$ & 147.5 & & \\
\hline $5^{\prime}$ & $\mathrm{C}$ & 129.7 & & \\
\hline $6^{\prime}$ & $\mathrm{CH}$ & 118.1 & $6.70 \mathrm{brs}$ & $\mathrm{C}-3^{\prime}, \mathrm{C}-4^{\prime}$ \\
\hline $7^{\prime}$ & $\mathrm{CH}_{2}$ & 32.9 & $2.62 t(7.3)$ & $\mathrm{C}-1^{\prime}, \mathrm{C}-2^{\prime}, \mathrm{C}-6^{\prime}, \mathrm{C}-8^{\prime}$ \\
\hline $8^{\prime}$ & $\mathrm{CH}_{2}$ & 32.9 & $1.85 t(7.3)$ & \\
\hline \multirow[t]{2}{*}{$9^{\prime}$} & $\mathrm{CH}_{2}$ & 69.9 & $3.90 t(7.3)$ & C- $8^{\prime}$ \\
\hline & & & $3.52 t(7.3)$ & \\
\hline $3^{\prime}-\mathrm{OMe}$ & $\mathrm{CH}_{3}$ & 56.8 & $3.81 \mathrm{~s}$ & \\
\hline $1^{\prime \prime}$ & $\mathrm{CH}$ & 104.5 & $4.20 d(7.3)$ & C- $9^{\prime}$ \\
\hline $2^{\prime \prime}$ & $\mathrm{CH}$ & 75.2 & $3.20 d d(7.3 / 8.5)$ & \\
\hline $3^{\prime \prime}$ & $\mathrm{CH}$ & 78.2 & $3.32 t(8.5)$ & \\
\hline $4^{\prime \prime}$ & $\mathrm{CH}$ & 71.7 & $3.25 t(9.4)$ & \\
\hline $5^{\prime \prime}$ & $\mathrm{CH}$ & 78.0 & $3.31 \mathrm{~m}$ & \\
\hline \multirow[t]{2}{*}{$6^{\prime \prime}$} & $\mathrm{CH}_{2}$ & 62.8 & $3.82^{\mathrm{b}}$ & \\
\hline & & & $3.63 d d(11.9 / 6.0)$ & \\
\hline
\end{tabular}

* The ${ }^{13} \mathrm{C}$ and ${ }^{1} \mathrm{H}$ assignments were based on HSQC, HMBC and COSY experiments.

${ }^{a}$ Unclear due to signal overlapping.

b Partly merged with the 3'-OMe signal. 
suggesting the presence of a $\beta$-glucopyranose unit within 1. Apart from six signals due to a $\beta$-glucopyranoside unit and three OMe signals, the ${ }^{13} \mathrm{C}$ NMR spectrum of 1 (Table I) contained 18 skeletal carbon resonances, which were classified as four methylenes, seven methines and seven quaternary carbon atoms by a DEPT-135 experiment. From the detailed inspection of these data, associated with the interpretation of the $2 \mathrm{D}$ NMR data, compound 1 was predicted to be 4- $O$-methyldihydrodehydrodiconiferyl alcohol-9'-O- $\beta$-glucoside. Accordingly, methine protons at $\delta 3.42$ (overlapped), which coupled to the oxymethine proton at $\delta 5.52(d, J=6.5 \mathrm{~Hz})$ in the gCOSY spectrum, were ascribed to $\mathrm{H}-8$ and $\mathrm{H}-7$ of the benzofuran ring, respectively. $\mathrm{H}-8$ showed additional coupling with the hydroxymethyl protons ( $\delta 3.80$, partly merged with OMe signal; $3.72, d, J=8.0 \mathrm{~Hz}, \mathrm{H}_{2^{-}}$ 9). Two methoxy functions were placed at C-3 and C-4 of the tetrasubstituted aromatic ring on the basis of prominent HMBC correlations shown in Fig. 2. Additional long-range couplings between H-8/C-9, H $2_{2}-9 / C-7$, H-7/C-1, H-7/C-2 and H-7/C-6 secured the aromatic substitution to take place at C-7. The assignments of the third methoxy group (C-3') as well as $\mathrm{H}-2^{\prime}$ and $\mathrm{H}-6^{\prime}$ of the benzofuran ring were also possible by the cross-peaks observed in the gHMBC spectrum (Fig. 2). Thus the

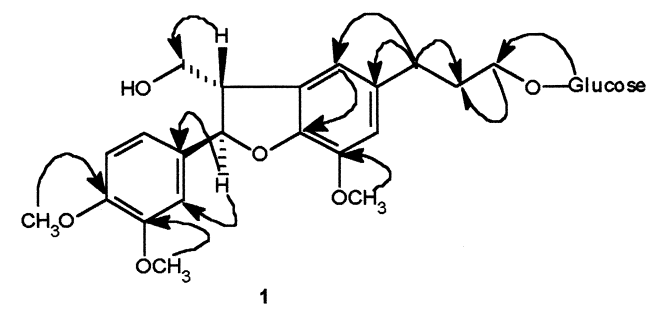

Fig. 2. Selected HMBC correlations for $\mathbf{1}$.

saturated side chain and the $\beta$-glucopyranoside unit were remained to be positioned. In the gCOSY spectrum, the benzylic methylene protons ( $\delta 2.62,2 \mathrm{H}, t, J=7.3 \mathrm{~Hz}, \mathrm{H}_{2}-7^{\prime}$ ) coupled with the $\mathrm{C}-8^{\prime}$ protons $(\delta 1.852 \mathrm{H}, t, J=7.3 \mathrm{~Hz})$. The latter showed further couplings with the oxymethylene protons $\left(\delta 3.901 \mathrm{H}, t, J=7.3 \mathrm{~Hz}, \mathrm{H}-9^{\prime}{ }_{\mathrm{b}}\right.$ and 3.52 $\left.1 \mathrm{H}, t, J=7.3 \mathrm{~Hz}, \mathrm{H}-9^{\prime}{ }_{\mathrm{a}}\right)$. Heteronuclear HMBC cross couplings between $\mathrm{H}_{2}-7^{\prime} / \mathrm{C}-1^{\prime}, \mathrm{H}_{2}-7^{\prime} / \mathrm{C}-2^{\prime}$, $\mathrm{H}_{2}-7^{\prime} / \mathrm{C}-6^{\prime}, \mathrm{H}_{2}-7^{\prime} / \mathrm{C}-8^{\prime}$ and $\mathrm{H}_{2}-9^{\prime} / \mathrm{C}-8^{\prime}$ indicated the attachment of the side chain at $\mathrm{C}-1^{\prime}$, as expected. The glycosidic linkage was determined to be at C-9' due to the downfield shift of the C$9^{\prime}$ ( $\delta$ 69.9), in addition to the HMBC correlation observed from $\mathrm{H}-1^{\prime \prime}(\delta 4.20)$ of the glucose moiety to $\mathrm{C}-9^{\prime}$ atom. Although, the stereochemistry at C7 and C-8 could not be established from the available data, but the negative optical rotation value of the mixture $\left([\alpha]^{D_{20}}-26^{\circ}\right)$ suggested that $\mathbf{1}$ may have the $(-)$ stereoisomeric structure (Abe and Yamauchi, 1986; Wang and Jia, 1997a). Consequently, compound 1 was identified as (-)-4-Omethyldihydrodehydrodiconiferyl alcohol- $9^{\prime}-O-\beta$ D-glucopyranoside. To the best of our knowledge, $\mathbf{1}$ is being reported for the first time in nature.

The complete analysis of the remaining ${ }^{1} \mathrm{H}$ and ${ }^{13} \mathrm{C}$ NMR signals, assigned by $2 \mathrm{D}$ NMR experiments (DQF-COSY, HSQC and HMBC) again, revealed that 2 was almost identical with 1 . However, the presence of two extra proton signals at $\delta$ $6.65(1 \mathrm{H}, d . J=11.0 \mathrm{~Hz})$ and $\delta 6.21(1 \mathrm{H}, d d, J=$ $11.0 / 7.3 \mathrm{~Hz})$ in 2 instead of the two methylene groups in 1, was indicative of an unsaturated sidechain. The olefinic bond was determined to be at $\Delta^{7^{\prime}, 8^{\prime}}$, based on the the results of the gCOSY and gHMBC experiments. The stereochemistry of $\mathbf{2}$ was also assumed to be (-) as in the case of $\mathbf{1}$. Therefore, the structure of $\mathbf{2}$ was established as (-)-4-O-methyldehydrodiconiferyl alcohol-9'-O$\beta$-D-glucopyranoside, which is identical to that of longifloroside A, previously isolated from Pedicularis longiflora (Scrophulariaceae) (Wang and Jia, 1997b).

(-)-Dihydrodehydrodiconiferyl alcohol-9- $O-\beta$ D-glucopyranoside (3) was identified by comparison of its physical and spectroscopic $\left({ }^{1} \mathrm{H}\right.$ NMR, ${ }^{13} \mathrm{C}$ NMR and ESIMS) data with those published in the literature (Abe and Yamauchi, 1986; Wang and Jia, 1997a; Saracoğlu et al., 2002).

Reports for the isolation of the lignan glucosides from the genus Phlomis are in limited number. Up to now, only the neolignan glucoside, (-)-dihydrodehydrodiconiferyl alcohol-9-O- $\beta$-D-glucopyranoside (3) from $P$. lycia (Saracoğlu et al., 2002) and the lignan glucoside, syringaresinol-4'-O- $\beta$-D-glucoside from $P$. fruticosa (Ersöz et al., 2001a) have been reported. Of the three lignan glucosides characterized from $P$. chimerae, compounds $\mathbf{1}$ and 3 were identified as dihydrodehydrodiconiferyl alcohol-type lignan glucosides, whereas $\mathbf{2}$ was a dehydrodiconiferyl alcohol-type glucoside. In addition to the new neolignan glucoside $\mathbf{1}$, this is the 
first demonstration of the occurence of (-)-4-Omethyldehydrodiconiferyl alcohol-9'-O- $\beta$-D-glucopyranoside (= longifloroside A) (2) and the second report for the isolation of (-)-dihydrodehydrodiconiferyl alcohol-9- $O$ - $\beta$-D-glucopyranoside (3) in the genus Phlomis.

\section{Acknowledgements}

The authors wish to thank Prof. Dr. Hayri Duman (Gazi University, Faculty of Science, Dept. of

Abe F. and Yamauchi T. (1986), Lignans from Trachelospermum asiaticum (Trachelospermum. II). Chem. Pharm. Bull. 34, 4340-4345.

Ersöz T., Saracoğlu İ., Harput Ü. S., Calıs İ. and Dönmez A. A., (2001a), Iridoid and phenylpropanoid glycosides from Phlomis grandiflora var. fimbrilligera and Phlomis fruticosa. Turk. J. Chem. (in press).

Ersöz T., Saracoğlu İ., Kırmızıbekmez H., Yalçın F. N., Harput Ü. S., Dönmez A. A. and Calıs İ. (2001b), Iridoid, phenylethanoid and phenol glycosides from Phlomis chimerae. Hacettepe University, Journal of Faculty of Pharmacy 21, 23-33.
Botany, Ankara, Turkey) for providing the plant material; Dr. Vajira Nanayakkara (University of Utah) for recording the ESIMS. Special thanks are to Pharm. Pinar Akbay and Dr. Engelbert Zass (ETH-Zurich) for performing literature searches. This work was supported by the Scientific and Technical Research Council of Turkey (TÜBİTAK Project No. SBAG-2304).

Saracoğlu İ., Harput Ü. S., Calıs İ. and Ogihara Y. (2002), Phenolic constituents from Phlomis lycia. Turk. J. Chem. 26, 133-142.

Wang C. Z. and Jia Z. J. (1997a), Lignan, phenylpropanoid and iridoid glycosides from Pedicularis torta. Phytochemistry 45, 159-166.

Wang C. Z. and Jia Z. J. (1997b), Neolignan glycosides from Pedicularis longiflora. Planta Med. 63, 241-244. Whiting D. A. (1985), Lignans and neolignans. Nat. Prod. Rep. 2, 191-211. 